\title{
Development of a bienzyme system for the electrochemical determination of nitrate under ambient air
}

\author{
YUE CUI*, JOHN P. BARFORD, REINHARD RENNEBERG \\ Department of Chemical Engineering and Department of Chemistry, Hong Kong University \\ of Science and Technology, Clear Water Bay, Kowloon, Hong Kong \\ Email: kecuiyue@ust.hk
}

\begin{abstract}
This work reports the development of a bienzyme system consisting of salicylate hydroxylase (SHL) and nitrate reductase $(\mathrm{NaR})$ for the electrochemical determination of nitrate. This method measures the concentration of nitrate directly under ambient air without suffering from oxygen interferences. The determination is based on the detection of NADH consumption, and the principle is as follows: NADH initiates the irreversible decarboxylation and hydroxylation of salicylate by SHL in the presence of oxygen to produce catechol, which results in a detectable signal due to its oxidation at the working electrode; the second enzyme $\mathrm{NaR}$, in the presence of nitrate, reduced the availability of $\mathrm{NADH}$, and consequently, the current difference after the injection of nitrate is proportional to its concentration. This method shows high performance characteristics for nitrate determination with a broad detection range between $10 \mu \mathrm{M}$ and $1000 \mu \mathrm{M}$, a short measuring time of around $5 \mathrm{~min}$, and a simple operation without sample pretreatment by inert gas purge or oxygen scavenger.

Keywords Electrochemical determination $\cdot$ Nitrate $\cdot N A D H \cdot$ Nitrate reductase $\cdot$ Salicylate hydroxylase
\end{abstract}

\section{Introduction}

Nitrate is a well-known alarming pollutant to both environment and human health. The excess nitrate in environmental water systems causes algal blooms, a depletion of dissolved oxygen, and possible eutrophication. Nitrate in the human body, causes methemoglobinemia (also called "baby blue syndrome"), and also may become a source of carcinogenic N-nitrosamines, some gastrointestinal cancers and teratogenic effects [1-3]. Predominantly considering human health, most countries have imposed limits for nitrate in drinking water of $25-50 \mathrm{mg} / 1(0.4-$ $0.8 \mathrm{mM})[4]$.

Due to the high specificity of nitrate reductase $(\mathrm{NaR})$ and the easy-to-handle operation of electrochemical device, various enzyme-based electrochemical detections for nitrate have been widely performed using combinations of $\mathrm{NaR}$ and different mediators to detect the 
electron-transfers [3-19]. However, the low redox potential of this enzyme and its matching mediators suffer from oxygen interferences. Therefore, these measurements require the dissolved oxygen to be removed from the sample by an inert gas purge or an oxygen scavenger prior to the analysis.

Besides the participation of mediators in the enzymatic reaction for nitrate, NADH could also be utilized as a cofactor by NaR. To the best of our knowledge, this feature hasn't been applied to the enzyme-based electrochemical determination of nitrate by the detection of NADH. Recently, salicylate hydroxylase (SHL) is used as a signal generator and a sensing unit for NADH in an electrochemical detection, which results in high performance characteristics [20]. In this work, we present an electrochemical determination of nitrate using a bienzyme system consisting of SHL and NaR, where both enzymes utilize NADH as a cofactor. This method is performed under ambient air, it has a simple operation without sample pretreatment by inert gas purge or oxygen scavenger to avoid the oxygen interferences, it is free from the uses of mediators, and also easy to adapt for the hand-held devices.

As shown in Fig. 1, the determination principle is as follows: NADH initiates the irreversible decarboxylation and hydroxylation of salicylate by SHL in the presence of oxygen to produce catechol, which results in a detectable signal due to its oxidation at the screen-printed working electrode. The presence of nitrate reduces the availability of NADH which is achieved by using $\mathrm{NaR}$, and further reduces the production of catechol at the working electrode and its oxidation current. Consequently, the stationary current difference after the injection of nitrate is proportional to the concentration of nitrate.

\section{Experimental}

\section{Apparatus}

A potentiostat EP30 (Biometria, Germany) and a computer installed with the software FIABOLO were used. The screen-printed electrode (BioSensorTrend, Germany) with a 2electrode configuration was composed of a platinum $(\mathrm{Pt})$ working electrode (diameter: $1 \mathrm{~mm}$ ) and an $\mathrm{Ag} / \mathrm{AgCl}$ reference/counter electrode. A measuring cell (volume: $1 \mathrm{ml}$ ), connected to a 
syringe and installed with two connectors (cathode and anode) and an electrode-fitting site, was constructed for experiments.

\section{Chemicals}

Salicylate hydroxylase (SHL, EC 1.14.13.1, from Pseudomonas sp.) was from GDS Technology Inc. (USA). Sodium salicylate was from Nacalia Tesque Inc. (Japan). Potassium nitrate was from Fisher Scientific (USA). Nitrate reductase (NaR, EC 1.7.1.1., from corn leaves) was from Nitrate Elimination Company Inc. (USA). 2-amino-2-(hydroxymethyl)-1, 3propanediol (TRIZMA®BASE, Tris), $\beta$-nicotinamide adenine dinucleotide hydrate reduced form (NADH), and glutaraldehyde were purchased from Sigma-Aldrich (USA). All solutions were prepared in double distilled water.

\section{Enzyme-electrode preparation}

The screen-printed working electrode was covered by a mixture containing $0.25 \mathrm{U}$ SHL and $1 \%$ glutaraldehyde (immobilization agent) in $0.5 \mu \mathrm{l}$ of enzyme matrix with high reproducibility, which was performed manually using an autopipet, followed by drying and storing at $4{ }^{\circ} \mathrm{C}$ overnight. The enzyme electrode was then screwed into the measuring cell, which was filled with buffer solution, and rehydrated for around $1 \mathrm{~h}$ at room temperature (20 $\left.{ }^{\circ} \mathrm{C}\right)$ to allow the enzyme matrix swelling before usage.

\section{Measurement for nitrate}

One $\mathrm{ml}$ of Tris-HCl buffer (100 mM, pH 8.0) containing $10 \mathrm{mM}$ salicylate, $1 \mathrm{mM}$ NADH, and $0.5 \mathrm{U} \mathrm{ml}^{-1} \mathrm{NaR}$ was added into the measuring cell which had been equipped with the SHL-based electrode. Experiments were performed at room temperature by applying the specific potential for this type of screen-printed electrode at $0.42 \mathrm{~V}$ (the recommended potential by BioSensorTrend) and magnetically stirring the buffer solution at $300 \mathrm{rpm}$. When a constant current was obtained, the measurement for nitrate was started by adding $100 \mathrm{mM}$ of standard nitrate solution $(0.1-20 \mu \mathrm{l})$ into the buffer, and until a stationary current occurred, the current difference was recorded for plotting the calibration curve. After the measurement, a syringe was used for sucking the buffer solution out of the measuring cell to remove nitrate, 
followed by the addition of a blank buffer (containing no nitrate) for starting a new measurement.

\section{Results and Discussion}

\section{Investigation of the enzyme electrode}

The effect of the enzyme matrix on electrode was investigated. Several enzyme electrodes, with the SHL loadings from $0.10 \mathrm{U}$ to $0.50 \mathrm{U}$ and glutaraldehyde loadings from $0.5 \%$ to $1.5 \%$, were compared by detecting $1 \mathrm{mM} \mathrm{NADH}$ in $100 \mathrm{mM}$ Tris- $\mathrm{HCl}$ buffer containing 10 $\mathrm{mM}$ salicylate at $\mathrm{pH} 8.0$ (see Electronic Supplementary Material, Fig. S1). From the investigation, a mixture containing $0.25 \mathrm{U} \mathrm{SHL}$ and $0.5 \%$ or $1 \%$ glutaraldehyde in $0.5 \mu \mathrm{l}$ of enzyme matrix on a screen-printed electrode showed a maximum current response, and 0.25 U SHL and $1 \%$ glutaraldehyde exhibited a better stability, which was used for further experiments.

\section{Investigation of the buffer solution}

To obtain an optimal buffer $\mathrm{pH}$ for the SHL-based electrode, the investigations were performed by measuring $1 \mathrm{mM} \mathrm{NADH}$ in $100 \mathrm{mM}$ Tris- $\mathrm{HCl}$ buffer containing $10 \mathrm{mM}$ salicylate at various $\mathrm{pH}$ values ranging from 6.5 to 10.0 (see Electronic Supplementary Material, Fig. S2). The maximum current response was obtained between $\mathrm{pH} 7.5$ and $\mathrm{pH} 8.5$. Therefore, $\mathrm{pH} 8.0$ which in the middle of the optimal $\mathrm{pH}$ range for the SHL-based electrode was used for other investigations.

The effect of salicylate was investigated on the performance of the SHL-based electrode. Various molar ratios of salicylate to NADH were tested by measuring $1 \mathrm{mM}$ NADH in 100 $\mathrm{mM}$ Tris-HCl buffer containing different amounts of salicylate at $\mathrm{pH} 8.0$ (see Electronic Supplementary Material, Fig. S3), and the saturated signal response was obtained at a molar ratio of 0.5 . In this work, a sufficient salicylate concentration of $10 \mathrm{mM}$ in buffer was used for other investigations in order to avoid the signal saturation due to its inadequate loading.

In the investigation of $\mathrm{NADH}$ concentration in buffer, the measurements for NADH were performed in $100 \mathrm{mM}$ Tris- $\mathrm{HCl}$ buffer containing $10 \mathrm{mM}$ salicylate at $\mathrm{pH} 8.0$ (see Electronic 
Supplementary Material, Fig. S4). A linear relationship was obtained between the current response and the concentration of $\mathrm{NADH}$ from $5 \mu \mathrm{M}$ to $3.6 \mathrm{mM}$. Thus, a NADH concentration in the linear detection range could be used for the determination of nitrate in order to obtain a sensitive detection range, a higher concentration of NADH resulted in a higher upper detection limit for nitrate while did not improve the lower detection limit, and 1 $\mathrm{mM} \mathrm{NADH}$ in buffer was chosen for the determination of nitrate. Also, the SHL-based electrode had a fast measuring time $(20 \mathrm{~s})$ for the detection of NADH.

The effect of $\mathrm{NaR}$ was investigated by measuring $1 \mathrm{mM}$ nitrate in $100 \mathrm{mM}$ Tris- $\mathrm{HCl}$ buffer containing $10 \mathrm{mM}$ salicylate, $1 \mathrm{mM} \mathrm{NADH}$ and various loadings of $\mathrm{NaR}\left(0.3 \mathrm{U} \mathrm{ml}^{-1}, 0.5 \mathrm{U}\right.$ $\mathrm{ml}^{-1}, 0.7 \mathrm{U} \mathrm{ml}^{-1}$ or $1.0 \mathrm{U} \mathrm{ml}^{-1}$ ) at $\mathrm{pH} 8.0$ (see Electronic Supplementary Material, Fig. S5). With the increasing of NaR loading in buffer solution from $0.3 \mathrm{U} \mathrm{ml}^{-1}$ to $1.0 \mathrm{U} \mathrm{ml}^{-1}$, the time for achieving a steady state after the injection of nitrate decreased from around 9 min to 2 min, while the enzyme loading did not affect the current response apparently, and $0.5 \mathrm{U} \mathrm{ml}^{-1}$ $\mathrm{NaR}$ with a steady-state measuring time of $5 \mathrm{~min}$ was used for the determination of nitrate. Also, the $\mathrm{pH} 8.0$ of the buffer solution was within the optimal $\mathrm{pH}$ range for $\mathrm{NaR}$ activity, which was from 7.5 to 8.5 .

\section{Electrochemical determination of nitrate}

Fig. 2 shows the calibration curve for nitrate using the bienzyme system. The measurements were performed with a SHL-based electrode containing $0.25 \mathrm{U}$ SHL and 1\% glutaraldehyde and a $100 \mathrm{mM}$ Tris-HCl buffer containing $10 \mathrm{mM}$ salicylate, $1 \mathrm{mM} \mathrm{NADH}$ and $0.5 \mathrm{U} \mathrm{ml}^{-1}$ $\mathrm{NaR}$ at $\mathrm{pH}$ 8.0. The buffer solution resulted in a constant anodic current at the working electrode due to the production of catechol from the SHL-catalyzed reaction of NADH with salicylate and oxygen, followed by the addition of nitrate into the buffer, and as the concentration of nitrate was proportional to the consumption of NADH due to the NaRcatalyzed reaction, it was further proportional to the decrease of catechol concentration at the working electrode and the decrease of the steady-state anodic current. As shown in the figure, a linear relationship was obtained between the current response (net current) and the concentration of nitrate from 10 to $1000 \mu \mathrm{M}$ with a detection limit of $5.6 \mu \mathrm{M}$ (slope: $487.1 \mathrm{nA}$ $\mathrm{mM}^{-1}, \mathrm{R}^{2}=0.9970, \mathrm{n}=3$ ). A sharp saturation at $1000 \mu \mathrm{M}$ was observed due to the NADH depletion by the enzymatic reaction of $\mathrm{NaR}$ for nitrate. 
Fig. 3 shows the current-time curve of the bienzyme system to various concentrations of nitrate. This method had a fast response of $2 \mathrm{~s}$, a short steady-state measuring time of around 5 min and a quick recovery of 1 min with high reproducibility at a $\mathrm{NaR}$ loading of $0.5 \mathrm{U} \mathrm{ml}^{-1}$, as shown in the figure. Hence, in this case, the determination of nitrate took around $5 \mathrm{~min}$, and the total operation time for one measurement was around 6 to $7 \mathrm{~min}$. The measuring time and the total operation time could be less at a higher $\mathrm{NaR}$ loading, and such as at a $\mathrm{NaR}$ loading of $1 \mathrm{U} \mathrm{ml}^{-1}$, the determination of nitrate took around $2 \mathrm{~min}$ and the total operation time was around $3 \mathrm{~min}$, while this would consume more enzymes and not affect the determination result.

The bienzyme system, including the enzyme electrode and the measuring buffer, was stored at $4{ }^{\circ} \mathrm{C}$ with the electrode in the absence of NADH, and the system was stable for the measurement of nitrate, which could maintain around $90 \%$ of the initial response after one week's usage by performing several measurements each day. The reduction of performance was probably due to the reduced lifetimes of enzymes during storage and the electrode surface fouling during measurements.

\section{Conclusions}

In this work, we have demonstrated an electrochemical measurement of nitrate using a bienzyme system consisting of SHL and NaR under ambient air. It shows high performance characteristics with a broad detection range, a short measuring time and a simple operation without sample pretreatment by inert gas purge or oxygen scavenger. Thus, we provide a new analytical approach for the determination of nitrate that is specific, sensitive, fast, and easy to handle.

\section{Acknowledgements}

The authors gratefully acknowledge Hong Kong Research Grant Council (HKUST6253-02P and 510-0091-02-44000-0) for the financial support. 


\section{References}

1 Rajeshwar K, Ibanez JG (1997) (eds) Environmental Electrochemistry, Academic Press, San Diego

2 Moorcroft MJ, Davis J, Compton RG (2001) Talanta 54 : 785-803

3 Cosnier S, Innocent C, Jouanneau Y (1994) Anal Chem 66: 3198-3201

4 Kirstein D, Kirstein L, Scheller F, Borcherding H, Ronnenberg J, Diekmann S, Steinrucke P (1999) J Electroanal Chem 474: $43-51$

$5 \quad$ Kiang CH, Kuan SS, Guibault GG (1978) Anal Chem 50: 1319-1322

6 Strehlitz B, Grundig B, Vorlop KD, Bartholmes P, Kotte H, Stottmeister U (1994) Fresen J Anal Chem 349: 676-678

7 Cosnier S, Galland B, Innocent C (1997) J Electroanal Chem 433: 113-119

8 Aylott JW, Richardson DJ, Russell DA (1997) Analyst 122: 77-80

9 Katz E, Heleg-Shabtai V, Bardea A, Willner I, Rau HK, Haehnel W (1998) Biosens Bioelectron 13: 741-756

10 Glazier SA, Campbell ER, Campbell WH (1998) Anal Chem 70: 1511-1515

11 Moretto LM, Ugo P, Zanata M, Guerriero P, Martin CR, Anal Chem 70: 2163-2166

12 Patolsky F, Katz E, Heleg-Shabtai V, Willner I (1998) Chem Eur J 4: 1068-1073

13 Borcherding H, Leikefeld S, Frey C, Diekmann S, Steinrucke P (2001) Anal Biochem 282: 1-9

14 Ramsay G, Wolpert SM (1999) Anal Chem 71: 504-506

15 Willner I, Heleg-Shabtai V, Katz E, Rau HK, Haehnel W (1999) J Am Chem Soc 121: 6455-6468

16 Da Sliva S, Shan D, Cosnier S (2004) Sensor Actuat B-Chem 103: 397-402

17 Duan D, Shim JH, Kim JD, Park HS, Cha GS, Nam H (2005) Anal Chem 77: 4467-4473

18 Wang XJ, Dzyadevych SV, Chovelon JM, Renault NJ, Ling C, Xia SQ, Zhao JF (2006) Talanta 69: 450-455

19 Willmer I (1998) Acta Polym 49: 652-662

20 Cui Y, Barford JP, Renneberg R (2006) Anal Biochem 354: 162-164 


\section{Captions}

Fig. 1 Schematic illustration of the principle for the determination of nitrate (SHL: salicylate hydroxylase, NaR: nitrate reductase. SPE: screen-printed electrode)

Fig. 2 Calibration curve for nitrate using the bienzyme system ( $\mathrm{n}=3$ ) (Enzyme electrode: $0.25 \mathrm{U}$ SHL and 1\% glutaraldehyde in $0.5 \mu \mathrm{l}$ of enzyme matrix. Buffer: $100 \mathrm{mM}$ Tris-HCl buffer containing $10 \mathrm{mM}$ salicylate, $1 \mathrm{mM}$ $\mathrm{NADH}$ and $0.5 \mathrm{U} \mathrm{ml}^{-1} \mathrm{NaR}$ at $\mathrm{pH} 8.0$ )

Fig. 3 Current-time curve of the bienzyme system to (a) $1000 \mu \mathrm{M}$ (b) $500 \mu \mathrm{M}$ and (c) $250 \mu \mathrm{M}$ nitrate with (w) washing step ( $\mathrm{n}=3$ ) (Enzyme electrode: $0.25 \mathrm{U}$ SHL and 1\% glutaraldehyde in $0.5 \mu 1$ of enzyme matrix. Buffer: $100 \mathrm{mM}$ Tris- $\mathrm{HCl}$ buffer containing $10 \mathrm{mM}$ salicylate, $1 \mathrm{mM} \mathrm{NADH}$ and $0.5 \mathrm{U} \mathrm{ml}^{-1} \mathrm{NaR}$ at $\mathrm{pH} 8.0$ ) 


\section{Figures}

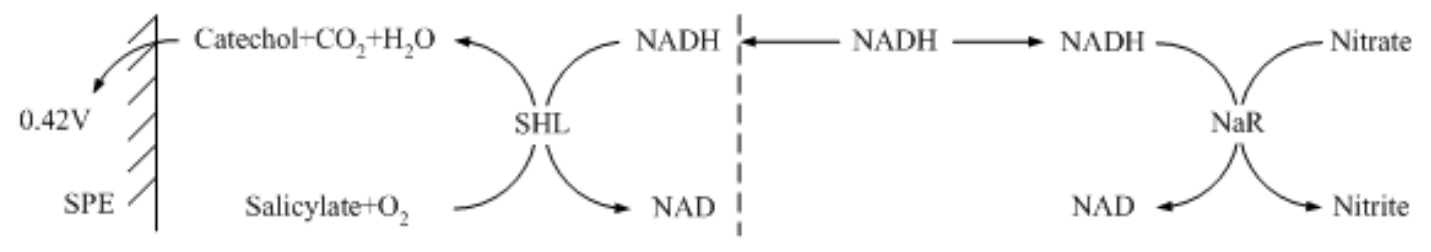

Fig. 1 Schematic illustration of the principle for the determination of nitrate (SHL: salicylate hydroxylase, NaR: nitrate reductase. SPE: screen-printed electrode) 


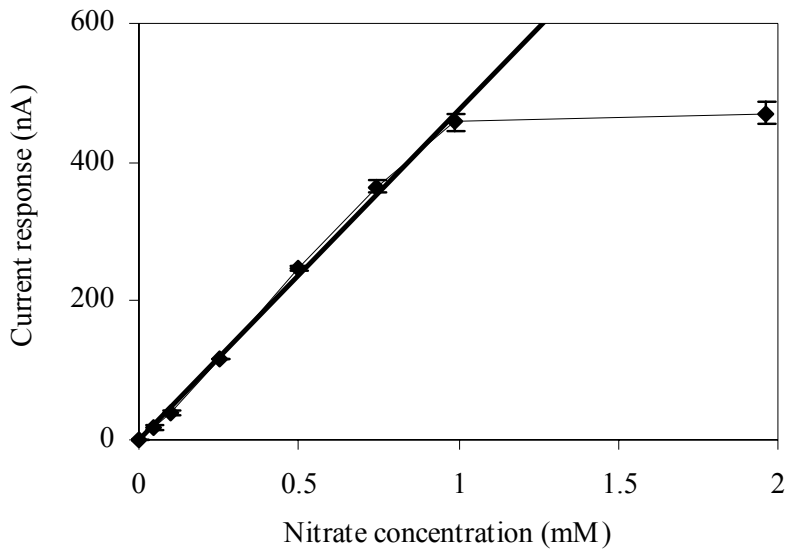

Fig. 2 Calibration curve for nitrate using the bienzyme system $(n=3)$ (Enzyme electrode: 0.25 U SHL and 1\% glutaraldehyde in $0.5 \mu \mathrm{l}$ of enzyme matrix. Buffer: $100 \mathrm{mM}$ Tris- $\mathrm{HCl}$ buffer containing $10 \mathrm{mM}$ salicylate, $1 \mathrm{mM}$ $\mathrm{NADH}$ and $0.5 \mathrm{U} \mathrm{ml}^{-1} \mathrm{NaR}$ at $\mathrm{pH} 8.0$ ) 


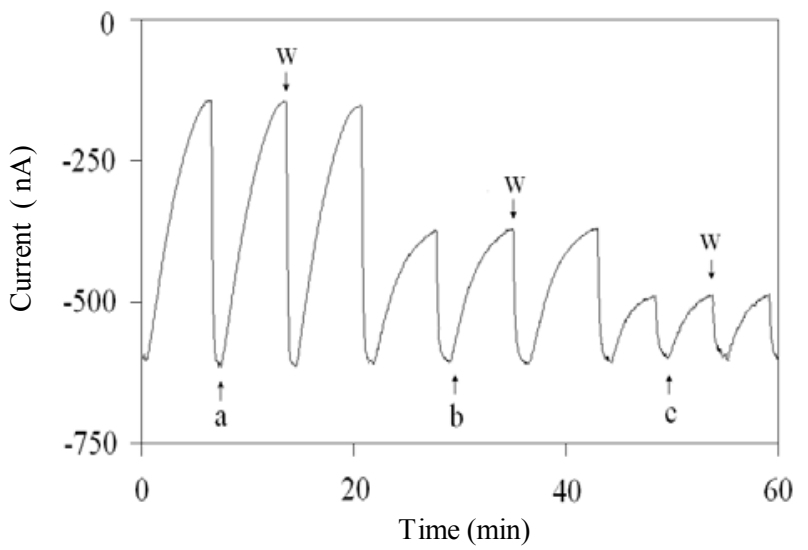

Fig. 3 Current-time curve of the bienzyme system to (a) $1000 \mu \mathrm{M}$ (b) $500 \mu \mathrm{M}$ and (c) $250 \mu \mathrm{M}$ nitrate with (w) washing step $(n=3)$ (Enzyme electrode: $0.25 \mathrm{U}$ SHL and 1\% glutaraldehyde in $0.5 \mu$ of enzyme matrix. Buffer: $100 \mathrm{mM}$ Tris- $\mathrm{HCl}$ buffer containing $10 \mathrm{mM}$ salicylate, $1 \mathrm{mM} \mathrm{NADH}$ and $0.5 \mathrm{U} \mathrm{ml}^{-1} \mathrm{NaR}$ at $\mathrm{pH} 8.0$ ) 